\title{
HUKUM POLIGAMI MENURUT UNDANG-UNDANG PERKAWINAN DAN FIKHI
}

\author{
Oleh :Ridwan Jamal
}

\begin{abstract}
Abstrak
Pasal 5 ayat (1) huruf A Undang-undang No. 1 Tahun 1974 tentang Perkawinan, yaitu mengenai adanya persetujuan istri/istriistri bagi suami yang mengajukan izin poligami, adalah bersifat mengatur kebolehan berpoligami, adalah sifat mengatur pelaksanaan kebolehan berpoligami, bukan menutup kebolehannya. Dalam pandang fikhi poligami diperbolehkan dengan beberapa persyaratan : Yang menikah adalah laki-laki, jumlahnya hanya dibatasi empat orang perempuan sesuai denga surat AnNisa ayat 3, dan kesanggupan lakilaki untuk dapat berbuat adil atas cinta, giliran menggaulinya, dan pemberian nafkah
\end{abstract}

\section{A. Pendahuluan.}

Poligami adalah beristri lebih dari dari satu. Kebalikannya adalah monogamy, ialah beristri satu.

Poligami ini mungkin merupakan pembawaan pria dari sejak jaman dahulu kala, baik dari bangsa Timur maupun bangsa Barat, lebih-lebih sebelum datangnya Islam, dimana seorang pria ada yang beristri puluhan atau bahkan ratusan.

Dan sebelum Nabi Muhammad SAW lahir, bangsa Arab terkenal sebagai bangsa yang suka bermusuh-musuhan satu kelompok dengan kelompok lain sehingga sering terjadi peperangan yang mengakibatkan banyaknya janda dan wanita sebagai tawanan atau pelayan.

Maka Islam berusaha menyelamatkan dan menghilangkan nasib/system perbudakan ini dengan bermacam-macam cara.

Lembaga-lembaga hukum untuk menyelamatkan dan menghilangkannya, diantaranya dengan system kafarat dengan memerdekakan hamba sahaya, seperti kafarat dari batal puasa dengan jima' kafarat dari pembunuhan, anj uran untuk memerde-kakan budak dengan pahala besar di syurga dan untuk menjamin para janda dengan membolehkan hermadu dan membatasasinya dengan empat orang wanita. 
Pemahaman kawin lebih dari satu hingga sampai saat ini masih menjadi persoalan yang hangat antara kebolehannya dengan ketidak bolehannya. Suatu persoalan yang semakin rumit diantaranya adalah mengenai jumlah laki-laki dan perempuan yang tidak seimbang, kondisi ekonomi, status social, dan hak-hak wanita

dan anak-anak terlantar lainnya, menyebapkan perlunya pemikiran dan petunjuk hukum mengenai boleti tidaknya atau mungkin bisa menjadi suatu keharusan bagi lakilaki untuk berpoligami.

Selanjutnya untuk kepentingan kemaslahatan tersebut diatas, maka yang menjadi rumusan masalah dalam makalah ini adalah bagaimana konsep Undang-undang perkawinan dan fikhi tentang poligami .

\section{B. Pembahasan}

Undang undang Nomor.1 Tahun 1974 tentang Perkawinan sudah berlaku hampir seperempat abad. Penyuluhan hukum tentang materi Undang-undang itu juga sudah cukup gencar dilakukan. Namun hingga saat ini temyata masih ada sementara umat Islam mempersoalkan bagian bagian tertentu dari Undang-undang terse-but. Tidak sedikit yang beranggapan ada yang bertentang-an dengan Al-Qur'an. Bukan itu saja, bahkan ada yang menghubung-hubungkan hal itu dengan krisis yang melanda Indonesia dewasa ini, bahwa itu adalah azab Allah sebagai akibat pelanggaran terhadap wahyunya.

Suara-suara bernada seperti ini tidak jarang terdengar di luar, tetapi ada juga yang disampaikan ke Departemen Agama, meminta direformasinya materi Undangundang yang dianggap bertentangan dengan Al-Qur'an itu. Terutama mengenai ketentuan persetujuan istri bagi suami yang ingin berpoligami.

Adanya persetujuan dari istri atau istri-istri bagi suami yang bermaksud ingin menikah lagi dengan wanita lain (berpoligami) adalah salah satu syarat untulk mengajukan permohonan izin berpoligami kepengadilan Agama (pasal 4 ayat (1) dan pasal 5 ayat (1) huruf a Undang-undang Nomor. 1 Tahun 1974 tentang perkawinan. ${ }^{1}$

\footnotetext{
${ }^{1}$ Zainal Abidin Abubakar, Kumpulan Peraturan Perundang-undangan dalam lingkunganPengadilan Agama,(Cet.III; Jaakrta: Yayasan AlHikmah, 1993), h.124.
} 
Selain persyaratan adanya persetujuan istri, masih terdapat dua persyaratan lagi, yaitu adanya kepastian bahwa suami yang bersangkutan mampu menjamin keperluan keperluan hidup istri dan anak-anak mereka dan adanya jaminan bahwa suami akan berlaku adil terhadap istri istri dan anakanak mereka (Pasal 5 ayat (1) huruf b dan c). ${ }^{2}$

Pengadilan Agama sebagai pelaksana kekuasaan Kehakiman bagi rakyat pencari keadilan bagi yang beragama Islam mengenai perkara Perdata tertentu, berwenang mengabulkan/mengizinkan atau tidak mengabulkan/tidak mengizinkan permohonan izin poligami yang diajukan oleh seorang suami (Pasal 10 ayat (1) Undang-undang No. 14 Tahun 1970 tentang Ketentuan-ketentuan Pokok Kekuasaan Kehakiman dan Pasal 49 Undang-undang No. 7 Tahun 1989 tentang Peradilan Agama serta Pasal 4 Undangundang No. 1 Tahun 1974 tentang Perkawinan ). Pengadilan Agama akan mmberikan izin kepada seorang suami untuk berpoligami apabila terbukti bahwa :

a. Istri tidak dapat menjalankan kewajiban sebagai istri.

b. Istri mendapat cacat badan atau tidak dapat disembuhkan.

c. Istri tidak dapat menlahirkan keturunan. ${ }^{3}$

Dari ketentuan peraturan perundangan tersebut diatas secara jelas dapat disimpulkan bahwa hukum tidak memberikan keleluasaan bagi para suami untuk melakukan perkawinan poligami. Undang-undang No. 1 Tahun 1974 bukan menganut azas monogamy. Seorang suami hanya dapat menikah lagi dengan wanita lain apabila is lebih daulu memenuhi persyaratan yang ditetapkan oleh undang-undang.

Ketidak sesuaian bagi suami untuk melakukan perkawinan poligami ini sama sekali tidak berarti peianggarang terhadap ketentuan Allah yang termaktub daiam surat An-Nisa ayat 3 :

Dan jika kamu tidak akan berlaku adil terhadap (hak-hak) perempuan yang yatim (bilamana kamu mengawininya), maka kawinilah wanita-wanita (lain) yang kamu senangi : dua, tiga, atau empat. Kemudian jika kamu takut tidak akan berlaku adil, maka kawinilah seorang saja,

\footnotetext{
${ }^{2}$ Ibid.

${ }^{3}$ Ibid.
} 
atau budak-budak yang kamu nziliki. Yang demikian itu lebih dekat kepada tidak berbuat aniaya. ${ }^{4}$

Ayat ini mengandung arti di antaranya :

1. Bahwa mula-mula diperbolehkannya poligami itu itu kalau merasa kuatir tidak terurusnya anak-anak yatim yang dipeliharanya dan untuk melindungi janda-janda yang ditinggalkan gugur oleh suaminya dalam perang sabil.

2. Meskipun seorang membutuhkan poligami karena banyak anak yatim yang dipeliharanya, akan tetapi kalau tidak sanggup berlaku adil terhadap istriistrinya itu mengenai nafkah, giliran dan sebagainya, diperintakan seorang saja (monogami).

3. Diperbolehkan poligami itu hanya karena keadaan kebutuhan yang mendesak. (Undangundang No.1 thn 1974 tentang perkawinan )

4. Berlaku adil yang sebenarnya mengenai lahir dan batin diantara istri-istri itu sangat sukar sekali.

Firman Allah surat An-Nisa ayat, 129 :

Dan kamu sekalian tidak akan dapat berlaku adil diantara istri istrimu itu walaupun kamu sekalian menginginkan demikian, maka oleh karena itu jangan kamu sekalian terlalu cenderung (kepada salah seorang istri yang sangat kamu sangat cintai), sehingga kamu biarkan yang lainnya terkatung katung, dan jika kamu mengadakan perbaikan (kemaslahatan) dan menjaga diri (dait kecurangan/tidak adil), maka sesungguhnya Allah adalah maha pengampun lagi maha penyayang. ${ }^{5}$

Surat An-Nisa ayat 3 diatas memperbolehkan perkawinan poligami, namun syarat keadilan suami, dalam ayat tersebut ditak tidak terdapat persyaratan lain bagi perkawinan poligami, padahal perkawinan semacam itu berdasarkan pengalaman empiris besar kemungkinan minimbulkan akibat negatif dalam kehidupan rumah tangga, baik pada mental spikologis, social amupun ekonomis. Akibat-akibat yang seperti itu akan merugikan seluruh

${ }^{4}$ Departemen Agama RI., AI-Qur'an dan Terjemahannya,(Jakarta : Yayasan Penterjemah Kitab Suci AlQur'an), h. 287.

${ }^{5}$ Ibid. 
anggota keluarga dan tentu saja tidak sejalan dengan hakikat dan tujuan perkawinan menurut ajaran Islam.

Islam adalah Agama yang sangat mengutamakan keberanian, keselarasan dan keseimbangan. Islam juga memberikan perhatian terhadap pentingnya ketertiban, ketenangan dan dan kebaikan dalam kehidupan masyarakat termasuk didalamnya kehidupan keluarga. Kepentingan orang lain hams diperhatikan pada setiap saat seseorang melaksanakan haknya. Kepentingan orang banyak atau umum hams didahulukan dari kepentingan pribadi. Kesewenang-wenangan dalam melaksakan dalam melaksanakan ibadah wajibpun, menurut tuntunan Islam, hendaklah tidak sampai mengganggu kepentingan orang lain atau masyarakat.

Maksud surat an-Nisa ayat 3 tersebut di atas dalam pelaksanaannya haruslah dihubungkan dengan ruh dan semangat ajaran agama Islam. Untuk itu mutlak diperlakukan ijtihad dalam rangka menemukan ketentuanketentuan hukum bagi kebolehan melakukan perkawinan poligami dimaksud, sementara dalam sumber-sumber otentik ajaran agama Islam secara eksplisit tidak dijumpai.

jtihad semacam itu sebenarnya bukan hal yang baru dalam sejarah perkembangan hukum Islam. Khalifah Umar bin al-Khattab terkenal mempunyai keberanian dan kebijaksanaan yang luar biasa dalam menerapkan hukum-hukum al-Qur'an untukmengatasi masalah-masalah yang, timbul dalam kehidupan masyarakat. Beliau menjadikan masalahmasalah yang timbul dalam kehidupan masyarakat.

Sebagai dasar dalam setiap pertimbangan dan pemikiran hukumnya. Terkadang di antara keputusan-keputusan hukum yang diambil oleh Umar ada yang kelihatannya bertentangan dengan nash-nash al-Qur'an tetapi yang bertentangan itu ternyata hanyalah "kelihatannya" saja. Pada hakikatnya keputusan-keputusan hukumnya itu tidak bertentangan dengan nash-nash al-Qur'an karena keberanian moril beliau melihat ayatayat itu secara lebih dalam dari pada apa yang tersurat saja. Para pakar dapat berbeda faham, tetapi tentang mutlak perlunya berijtihad dalam hal-hal seperti itu, tidak seorang pun yang mengingkarinya.

Dan kelihatan Khalifah Umar dalam ilmu hukum diakui oleh semua pihak. Tiada seorang pun yang menolaknya, sebagaimana yang antara lain dapat dilihat dari pertanyaan Mujahid yang mengatakan, "Apabila orangberselisih tentang sesuatu, maka 
lihatiah kepada apa yang diperbuat oleh Umar dan ambillah itu "Ibnu al-Alusayvab bahkan mengatakan, "Tiada seorang pun sesudah Rasulullah lebih mengetahui dari pada Umar ibnu alKhattab. ${ }^{6}$

Akan halnya akan ketentuan pasal 5 ayat (1) huruf a Undangundang No.1 Tahun 1974 yang berbunyi " Adanya persetujuan dari istri/istri-istri" sebagai sala satu syarat bagi suami yang ingin mengajukan permohonan izin poligami ke Pengadilan Agama, para perumus Undang-undang tesebut, khususnya dari kalangan umat Islam, jelas tidak berbuat sekehendak hati dan tanpa mengindakan ketentuan-ketentuan Al-Qur'an khususnya surat AnNisa ayat 3 sebagaimana dituduhkan sebagian orang. Lahirnya ketentuan pasal tersebut adalah berdasarkan pertimbangan matang dan mendalam yang mengacu pada " mashlahah al ummah" dan tujuan syariat perkawinan itu sendiri. Terlebih-lebih lagi mengingat kenyataan tidak sedikit suami yang sewenang-wenang melakukan perkawinan poligami secara berlebihan dan menyala gunakan kebolehan yang diberikan oleh Surat AnNisa ayat 3 itu, yang mengakibatkan terlantarnya kepentingan istri dan anak-anak. Suatu hal yang bertentangan dengan prinsip ajaran Islam.

Tidak perlu dipungkiri, memang ada sebagian suami mendapatkan kebaikan (kemaslahatan) dari perkawinan poligaminya. Tetapi tak dapat dipungkiri juga perkawinan poligami tersebut dapat membawa kerusakan (mafsadat) bagi kehidupan keluarganya, apabila dilakukan tanpa alasan, pertimbangan yang matang, dan pikiran yang jerni. Berdasarkan cara berfikir hukum Islam, menghindarkan kemungkinan datangnya kerusakan (mafsadat) haruslah lebih diuraman dari kemungkinan memperoleh kebaikan (maslahah). Kaidah fikhiyah menyebutkan : "Dar'u al mafaasid nzugaddam 'alajalb al-mashalih." ${ }^{7}$

Husein Bahreij menegaskan : poligami adalah sebagai jalan keluar bagi wanitawanita yang ditinggal mati oleh suaminya di medan perang atau mungkin dari sebap-sebap lain, sehingga wanitawanita itu pun tidak langsung terjerumus kedalam lembah perzinaan karena kini mereka telah memiliki suami-suami yang baru dalam bentuk poligami. Apabila poligami itu dilarang akan mengakibatkan kelahiran anakanak zina yang cukup banyak atau

${ }^{6}$ Zufran Sabrie, Mimbar Hukumi,(Al-Hikmah : no. 39 thn.IX September-Oktober 1998), h.33.

${ }^{7}$ H. Moh Anwar, Fiqih Islam,( Cet. II; PT.A1-Ma'rif 1988), h. 149. 
bayi-bayi yang akan digugurkan oleh ibunya atau bayi yang dibunuh karena tidak tahan dengan rasa malu jika menggendong anak haasil perzinahan. Atau banyaknya penyakit kelamin baik dikalangan pria maupun wanita sebagai akibat dari perzinahan bebas.

Disamping itu sebagai saran menghindarkan dari poligami ialah antara lain dengan mengusahakan dengan adanya kerukunan rumah tangga, tidak saling mencurigai, tidak mudah cemburu, sama-sama mawas diri, terutama bagi si istri harus bisa memelihara kesehatan dan keluwesan dirinya, bisa menarik pandangan mata dan had suaminya, lebih lebih bila suaminya sedang lelah, maka ia haruslah pandai menghibur dan mernbantu suami seperti halnya dalam hal kesusahan dan kesulitan, seperti yang dilakukan oleh Siti Khadija terhadap Nabi Muhammad Saw., ia pandai merayu dan tidak membosankan bila sedang berhubungan intim. Bila perlu, pakailah alat-alat kecantikan yang menggiurkan had sang suami dan galian singset yang menyedapkan. ${ }^{8}$

\section{Kesimpulan.}

Dari poin-poin diatas dapatlah ditarik kesimpulan bahwa bunyi pasal 5 ayat (1) huruf A Undang-undang No. 1 Tahun 1974 tentang Perkawinan, yaitu mengenai adanya persetujuan istri/istriistri bagi suami yang mengajukan izin poligami, adalah bersifat mengatur kebolehan berpoligami, adalah sifat mengatur pelaksanaan kebolehan berpoligami, bukan menutup kebolehannya.

Usul dari segelintir orang agar ketentuan pasal 5 ayat (1) huruf a dari Undangundang No. 1 Tahun 1974 tentang perkawinan, yaitu dengan meniadakan persetujuan istri/istri-istri adalah tidak beralasan, sehingga karena itu tidak dapat diterimah. Mengaitngaiiikan ketentu itu dengan krisis/azab adalah kebablasan dan tidak dengan persoalan ini.

Dalam pandang fikhi poligami diperbolehkan dengan beberapa persyaratan : Yang menikah adalah laki-laki, jumlahnya hanya dibatasi empat orang perempuan sesuai denga surat AnNisa ayat 3, dan kesanggupan lakilaki untuk dapat berbuat adil atas cinta, giliran menggaulinya, dan pemberian nafkah

\footnotetext{
${ }^{8}$ Sudarso, Pokok-pokok Hukum Islam,(Cet. I; Jakarta : Rineka Cipta, 1992), h. 223.
} 


\section{KEPUSTAKAAN}

Departemen Agama RI., Al-Qur'an dun TerjemahannYa, Jakarta : Yayasan Penerjemah Kitab Suci 1988

Sudarso, Pokok-pokok Hukttm Islam, Cet. 1; Jakarta : Rineka Cipta,-T992.

H. Moh. Anwar, Fiqih Islam, Cet. II; Jakarta : AlMa'arif, 1998.

Zufran Sabri, Mimbar Hukum, Al- Hikmah : No. 39 thn. 1998.

Zainal Abidin Abubakar, Kumpulan Peraturan Perundang Undangan claim lingkungan Peradilan Agama, Cet : III; Jakarta : Yayasan Al- Himah, 1993. 